\title{
Hemolymph ammonia and urea and nitrogenous excretions of Scylla serrata at different temperature and salinity levels
}

\author{
Jiann-Chu Chen*, Peng-Gek Chia \\ Department of Aquaculture, National Taiwan Ocean University, Keelung, Taiwan 20224, Republic of China
}

\begin{abstract}
Hemolymph ammonia and urea levels and nitrogenous excretions of Scylla serrata (Forskal) $(202 \pm 18 \mathrm{~g})$ were measured when the crabs were exposed to 9 different temperature and salinity regimes $\left(15,25,35^{\circ} \mathrm{C}\right.$ combined with 10,25 and $40 \%$ S). Hemolymph ammonia increased with a decrease in salinity, whereas hemolymph urea increased with an increase in salinity. Nitrogenous excretion increased with temperature. Excretion of ammonia- $N$, organic- $N$, nitrite- $N$, and nitrate- $N$ and total nitrogen excretion ( $\left.\mathrm{gg} \mathrm{g}^{-1} \mathrm{~h}^{-1}\right)$ increased with a decrease in salinity, whereas urea-N excretion increased with an increase in salinity. At $25^{\circ} \mathrm{C}$, ammonia- $\mathrm{N}$ excretion accounted for $82.0,79.2$ and $56.2 \%$ of total nitrogen excreted by the crabs at 10,25 and $40 \% \mathrm{~S}$, whereas urea- $\mathrm{N}$ excretion accounted for $4.3,9.1$ and $30.1 \%$ respectively. It is concluded that the S. serrata at $40 \%$ S shifts its excretory pattern from ammonıtelism to ureotelism.
\end{abstract}

KEY WORDS: Scylla serrata. Temperature Salinity Hemolymph Ammonia - Urea - Nitrogenous excretson - Metabolism

\section{INTRODUCTION}

Serrated crabs, also known as mud crabs, Scylla serrata (Forskal), generally inhabit intertidal flats and mangroves throughout the Indo-West Pacific region. Adult crabs inhabit pools and puddles in the littoral zone and migrate into estuaries after mating Their eggs and resultant zoeae are released in full strength seawater. As soon as they metamorphose to juveniles, they move inshore again. Crabs which are found in the littoral zone are likely to encounter variable salinity levels (Hill et al. 1982, Davenport \& Wong 1987)

In any aquatic system, temperature and salinity are considered to be the major factors that limit the distribution of invertebrates. Scylla serrata larvae can tolerate temperatures down to $5^{\circ} \mathrm{C}$, but they are inactive below $10^{\circ} \mathrm{C}$ (Hill 1974). The larvae show considerable mortality at salinity levels below $17.5 \%$, however the juveniles survive at salinity levels in the range 2 to

•E-mail: jcchen@mvax31.ntou.edu.tw
$60 \%$. Davenport \& Wong (1987) reported that young crabs (carapace length 60 to $100 \mathrm{~mm}$ ) survived for $4 \mathrm{~d}$ when they had been transferred from $35 \%$ to salinity in the range 2 to $32 \%$. The suitable level of salinity and temperature for the larvae is in the range 25 to $30 \%$, and 26 to $30^{\circ} \mathrm{C}$, respectively (Chen \& Cheng 1980 ).

In decapod crustaceans, ammonia, amino acids and urea are the 3 main end-products of nitrogen metabolism and are released mainly through the gill epithelium (Regnault 1987). Among nitrogenous wastes, ammonia-N (un-ionized plus ionized ammonia as nitrogen), which is the least expensive with regard to energy expenditure, makes up $86 \%$ of total excreted nitrogen in the shore crab Carcinus maenas (Needham 1957).

The effects of temperature and salinity on nitrogen excretion have been reported for Carcinus maenas (Haberfield et al. 1975, Spaargaren 1982, 1985, Harris \& Andrews 1985). In order to understand how the nitrogenous excretion of crabs is affected under different temperature and salinity levels, we examined hemolymph ammonia and urea and nitrogenous excre- 
tions of Scylla serrata at different temperature and salinity levels in the laboratory.

\section{MATERIALS AND METHODS}

Seawater (34\% S) pumped from the Keelung coast (Taiwan) adjacent to the National Taiwan Ocean University was adjusted to $40 \%$ with concentrated seawater and to 25 and $10 \%$ with municipal water that had been dechlorinated with sodium thiosulfate, then filtered through a gravel and sand bed by air-lift and aerated for $3 \mathrm{~d}$ before use.

Scylla serrata collected from a crab farm in Iilan, Taiwan, were shipped to our laboratory and divided into 9 groups held in $25 \%$ seawater at $25^{\circ} \mathrm{C}$ for $1 \mathrm{wk}$. Salinity was then adjusted, a decrease or increase of 2 to $3 \%$ per day with dechlorinated municipal water or concentrated seawater, until salinity levels of 10,25 and $40 \%$ were reached. Two thirds of the crabs at each salinity level were then transferred into another 6 tanks with expected final temperatures of 15 or $35^{\circ} \mathrm{C}$, and one third of crabs remained at $25^{\circ} \mathrm{C}$. The temperature was adjusted, a decrease or increase of 2 to $4^{\circ} \mathrm{C}$ per day, until the temperature levels of 15 and $35^{\circ} \mathrm{C}$ were reached. The animals were then acclimated to each test solution for $1 \mathrm{wk}$ prior to the experiment. During the acclimation, the crabs were fed clam Meretrix lusoria twice a day, but were not fed $1 \mathrm{~d}$ prior to the experiment.

There were 9 test solutions $(15,25$ and $40 \%$ combined with 15,25 and $35^{\circ} \mathrm{C}$ ), and each treatment was conducted in 5 replicates with 1 crab in each replicate. Circular tanks (20 l capacity) were filled with $10 \mathrm{l}$ of each test solution. Crabs at the intermolt stage were used for the study. The molt cycle stage was determined by the observation of cuticle at the edge of the flattened dactyl segment (paddle) in the fifth walking leg (Freeman et al. 1987). The total number of crabs used was 45. The average wet weight of crabs fasted. for $1 \mathrm{~d}$ prior to the experiment was $202 \pm$ $18 \mathrm{~g}$, respectively, and no significant difference in weight among treatments was observed.

The crabs were exposed individually from each acclimated test solution to each new test solution (10 l), with measurements of ammonia-N (Solorzano 1969), urea-N (McCarthy 1970), nitrite- $N$ (Bendschneider \& Robinson 1952), nitrate-N (Wood et al. 1967) and total nitrogen (Solorzano \& Sharp 1980) at the be- ginning of the experiment and $24 \mathrm{~h}$ later. Concentration of organic- $\mathrm{N}$ was calculated based on the differences among total nitrogen, ammonia- $N$, urea- $N$, nitrite- $N$ and nitrate-N. During the experiment, mean water DO (dissolved oxygen) and $\mathrm{pH}$ (mean $\pm \mathrm{SD}$ ) were $6.58 \pm$ $1.13 \mathrm{mg} \mathrm{l}^{-1}$ and $8.13 \pm 0.18$, respectively, with no significant difference among the treatments.

The differences in concentrations of ammonia-N, urea- $\mathrm{N}$, nitrite- $\mathrm{N}$, nitrate- $\mathrm{N}$, organic- $\mathrm{N}$ and total nitrogen between the beginning and end of the experiment were recorded. Weight specific ammonia- $\mathrm{N}$ excretion, urea- $\mathrm{N}$ excretion, nitrite- $\mathrm{N}$ excretion, nitrate- $\mathrm{N}$ excretion, organic- $N$ excretion and total nitrogen excretion ( $\mu \mathrm{g} \mathrm{g}^{-1} \mathrm{~h}^{-1}$ ) were calculated by multiplying water volume of each tank, and dividing by wet body weight and time lapse.
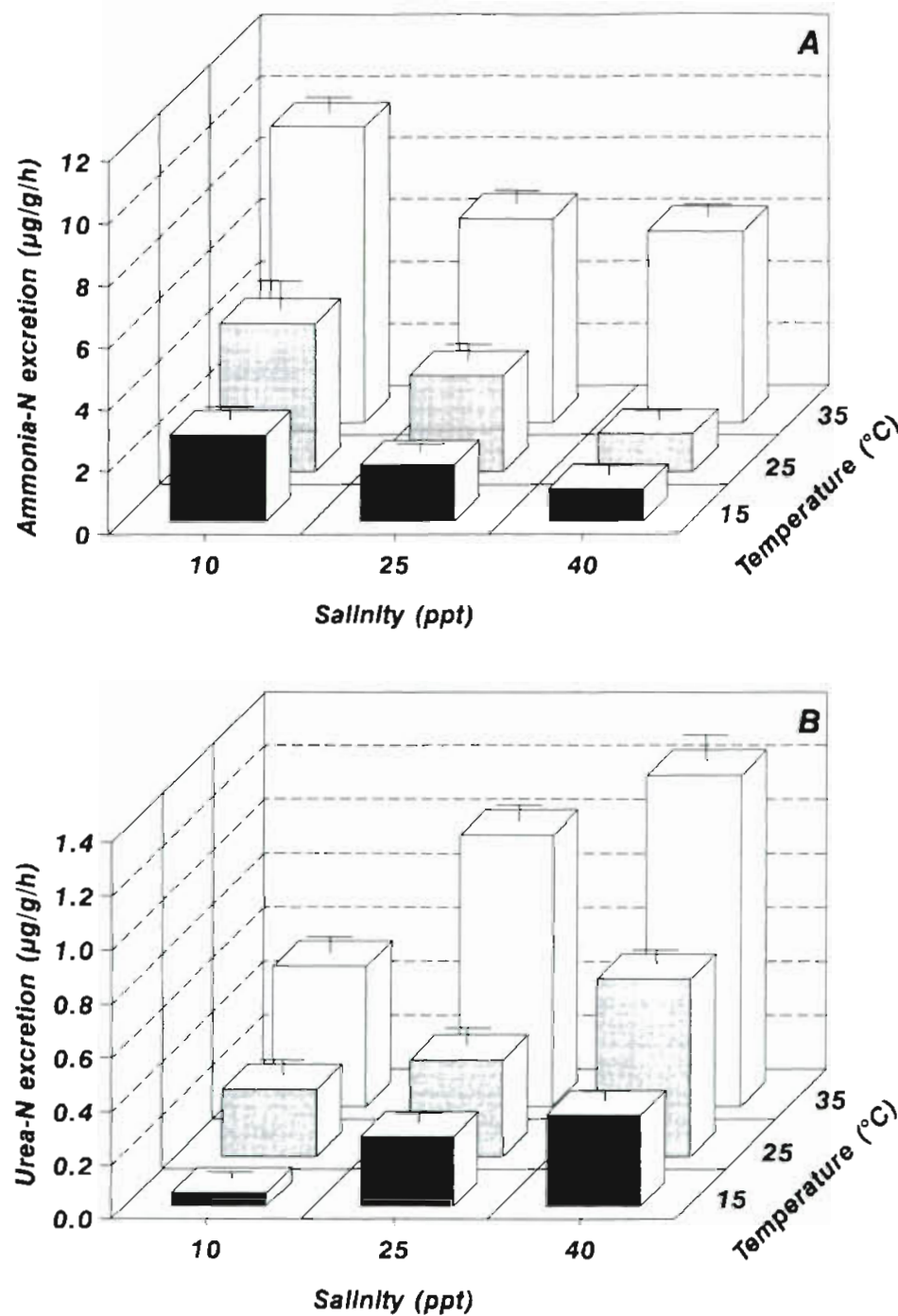

Fig. 1. Scylla serrata. Mean $\pm \mathrm{SE}$ (A) ammonia-N excretion and $(B)$ urea$N$ excretion of crabs mantained at different salinities and temperatures after 24 h. $n=5$ 
After $24 \mathrm{~h}$ exposure to each test solution, hemolymph samples were taken individually by inserting a syringe (25-gauge $\times 1$ ") into the body cavity via the proximal arthrodial membrane at the base of the right second walking leg. Hemolymph ammonia- $N$ and hemolymph urea- $N$ were measured colorimetrically with the methods of glutamate dehydrogenase (Sigma Procedure, No. 170) and diacetylmonoxime (Sigma Procedure, No. 535), respectively, as reported by Chen \& Cheng (1995).

All data were subjected to 1-way and 2way analyses of variance (Steel \& Torrie 1980). If significant differences were indicated at the 0.05 level, then Duncan's Multiple Range test was used to identify significant differences between treatments (Duncan 1955). The linear relationships among ammonia- $\mathrm{N}$ excretion, urea- $\mathrm{N}$ excretion, organic-N excretion, nitrite- $N$ excretion, nitrate- $N$ excretion, total nitrogen excretion, hemolymph ammonia-N, hemolymph urea$N$, temperature and salinity were tested using the General Linear Model Procedure and Regression Procedure, version 6.03, SAS (Statistical Analysis System) computer software (SAS 1988). All statistical significance tests were at the $p<0.05$ level.

\section{RESULTS}

Nitrogenous excretion of crabs increased significantly with an increase in temperature at all salinity levels. Ammonia- $N$ excretion decreased with an increase in salinity (Fig. 1A), whereas urea-N excretion increased significantly with an increase in salinity at all 3 temperature levels (Fig 1B).

At $15^{\circ} \mathrm{C}$, organic- $\mathrm{N}$ excretion of crabs decreased with an increase in salinity, whereas at 25 and $35^{\circ} \mathrm{C}$, no significant difference in organic- $\mathrm{N}$ excretion was observed among the 3 salinity levels (Fig. 2A). Total nitrogen excretion (Fig. 2B), nitrite-N excretion (Fig. 3A) and nitrate-N excretion (Fig. 3B) increased significantly with a decrease in salinity.

Statistical analysis indicated that there was a significant effect of temperature on all nitrogenous excretions and a significant effect of salinity on all nitrogenous excretions except organic-N excretion. There was also a significant interaction between the effects of temperature and salinity on all nitrogenous excretions except organic-N excretion (Table 1). The relationship between ammonia- $N$ excretion (ANE), urea- $N$ excre-
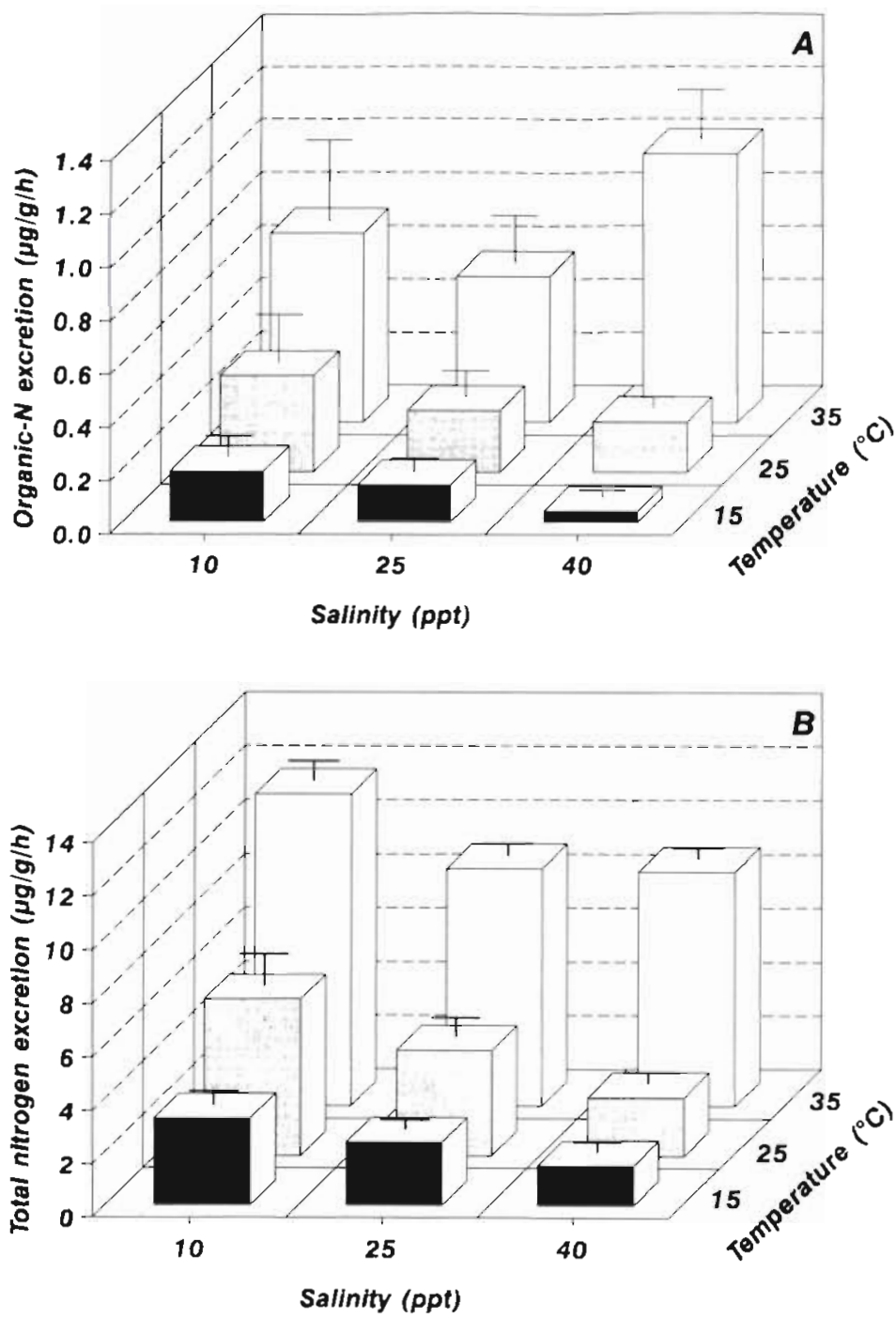

Fig. 2. Scylla serrata. Mean $\pm \mathrm{SE}$ (A) organic-N excretion and (B) total nitrogen excretion of crabs mantained at difterent salinil iss and temperatures after 24 h. $n=5$

tion (UNE), organic-N excretion (ONE), nitrite-N excretion (NINE), nitrate-N excretion (NANE), total nitrogen excretion (TNE), temperature (T), salinity (S) and the interaction between temperature and salinity (TS) is as follows:

$$
\begin{aligned}
\mathrm{ANE} & =-2.1378+0.3452 \mathrm{~T}-0.0304 \mathrm{~S}-0.0027 \mathrm{TS} \\
\left(\mathrm{R}^{2}\right. & =0.8278) \\
\mathrm{UNE} & =-0.3233+0.0179 \mathrm{~T}-0.0019 \mathrm{~S}+0.0007 \mathrm{TS} \\
\left(\mathrm{R}^{2}\right. & =0.8954) \\
\mathrm{ONE} & =-0.4180+0.0316 \mathrm{~T} \\
\left(\mathrm{R}^{2}\right. & =0.4283) \\
\mathrm{NINE} & =-0.2208+0.0253 \mathrm{~T}+0.0019 \mathrm{~S}-0.0004 \mathrm{TS} \\
\left(\mathrm{R}^{2}\right. & =0.8635) \\
\mathrm{NANE} & =-0.1435+0.0144 \mathrm{~T}+0.0025 \mathrm{~S}-0.0003 \mathrm{TS} \\
\left(\mathrm{R}^{2}\right. & =0.8925)
\end{aligned}
$$


TNE $=-2.7590+0.4154 \mathrm{~T}-0.0471 \mathrm{~S}-0.0019 \mathrm{TS}$

$\left(R^{2}=0.8267\right)$

The percentage of each nitrogenous excretion to total excreted nitrogen is given in Table 2. At $25^{\circ} \mathrm{C}$, ammonia- $N$ excretion accounted for $82.02,79.24$ and $56.16 \%$ of total nitrogen, whereas urea-N excretion accounted for 4.28, 9.11 and 30.14 of total nitrogen excreted by the crabs at 10,25 and $40 \%$, respectively.

At 25 and $40 \%$, hemolymph ammonia- $\mathrm{N}$ increased with a decrease in temperature. At 25 and $35^{\circ} \mathrm{C}$, hemolymph ammonia- $N$ was lowest at $40 \%$ (Fig. $4 \mathrm{~A}$ ). For the 3 temperature levels, hemolymph urea- $\mathrm{N}$ increased with salinity (Fig. 4B).

Statistical analysis indicated that there were significant effects of temperature and salinity on hemolymph ammonia- $N$ and urea- $N$, and that there was a significant
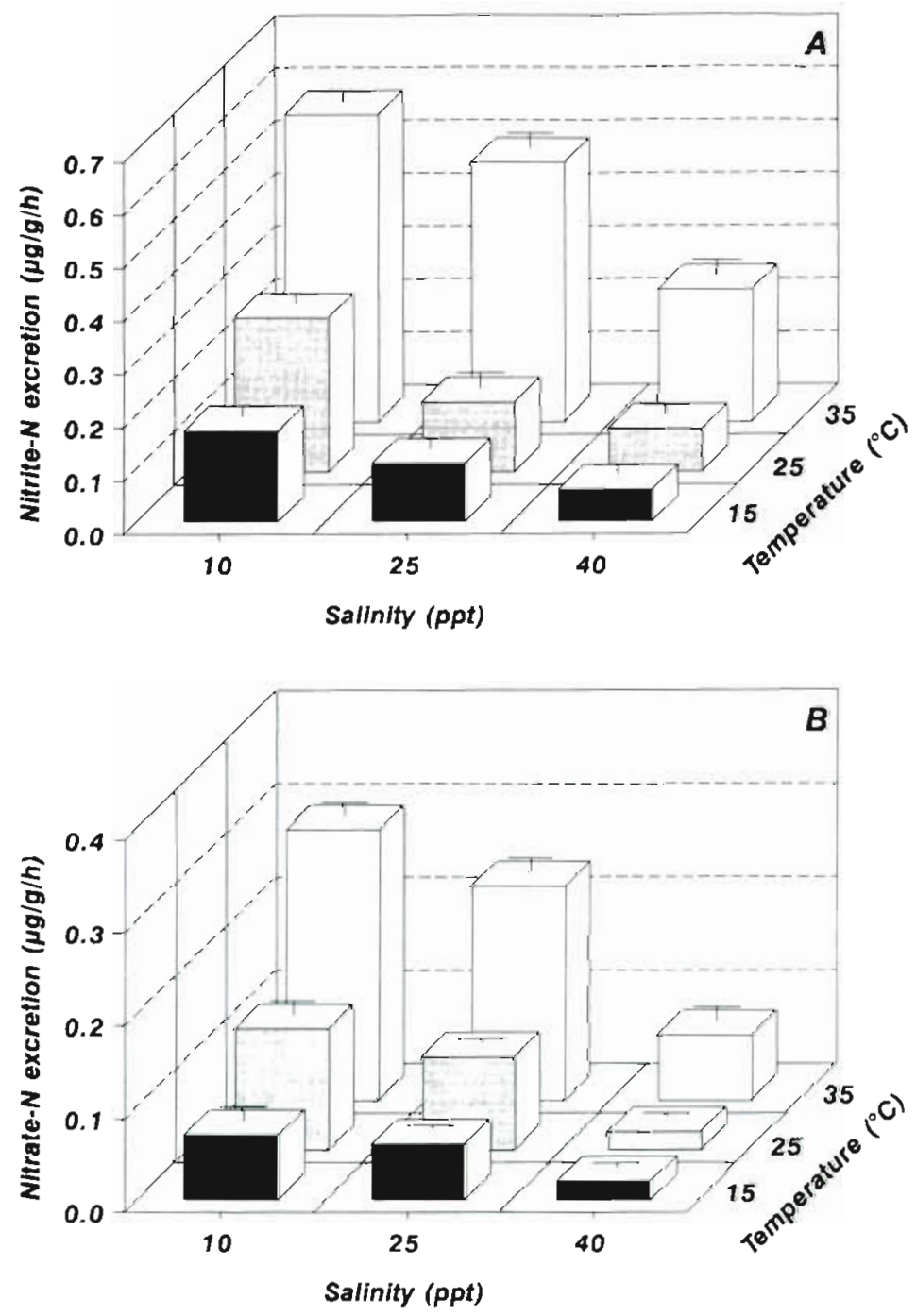

Fig. 3. Scylla serrata. Mean $\pm \mathrm{SE}$ (A) nitrite- $\mathrm{N}$ excretion and (B) nitrate-N excretion of crabs maintained at different salinities and temperatures after 24 h. $n=5$ interaction between the effects of temperature and salinity on the hemolymph ammonia-N and urea-N (Table 3 ). The relationship between hemolymph ammonia- $N$ (HAN), urea-N (HUN), T, S and TS is as follows:

$$
\begin{aligned}
\mathrm{HAN} & =6.9551+0.0981 \mathrm{~T}+0.0391 \mathrm{~S}-0.0061 \mathrm{TS} \\
\left(\mathrm{R}^{2}\right. & =0.5456) \\
\mathrm{HUN} & =-31.7550+1.3190 \mathrm{~T}+3.9140 \mathrm{~S}-0.0990 \mathrm{TS} \\
\left(\mathrm{R}^{2}\right. & =0.7148)
\end{aligned}
$$

\section{DISCUSSION}

Regnault (1987) reported that in decapod crustaceans, nitrogen was excreted mainly as ammonia that accounted for 60 to $70 \%$ of total excreted nitrogen, amino acids that accounted for $10 \%$ of total excreted nitrogen, and small amounts of urea and uric acids. Ammonia-N excretion is considered an indicator which reflects protein and energy utilization in crustaceans under various stressful environments (Nelson et al. 1977). An increase in ammonia excretion with increasing temperature has been observed in the shore crab Carcinus maenas (Needham 1957).

At low salinity $(10 \%)$, an increase in ammonia- $N$ excretion suggests that there is an increasing catabolism of amino acids, as was documented in Carcinus maenas by Haberfield et al. (1975). The catabolism of amino acids is considered to be involved in osmotic regulation when animals are subjected to low salinity. Free amino acids (FAA) have been considered to play an important role in the regulation of intracellular osmolality of crustaceans in acclimation to hypoosmotic or hyperosmotic media (Boone \& Claybrook 1977. Gilles \& Pequeux 1983) At higher salinity levels, an increase in tissue FAA has been recorded in C. maenas (Siebers et al. 1972), in Penaeus monodon (Fang et al. 1992) and in P. japonicus (Dalla Via 1986). FAA may contribute more than 40 to $60 \%$ of the intracellular osmolality (Robertson 1961, Smith \& Dall 1991). Studying northern brown shrimp $P$. aztecus, Bishop \& Burton (1993) documented that taurine dominates the amino acid pool at low salinity, while proline dominates it at higher salinity. Unfortunately, we measured FAA in neither tissue nor hemolymph in the present study.

The excretion of ammonia- $N$, urea- $N$ and organic- $N$ has been found to account for, respectively, 61,23 and $16 \%$ of total nitrogen excreted for green tiger prawn Penaeus 
Table 1 Scylla serrata. ANOVA table of ammonia-N excretion (ANE), urea-N excretion (UNE), nitrite- $N$ excretion (NINE), nitrate-N excretion (NANE), organic-N excretion (ONE) and total nitrogen excretion (TNE) of crabs maintained at different salinities (S) and temperatures (T) for $24 \mathrm{~h}$

\begin{tabular}{|c|c|c|c|c|c|}
\hline Source & $\mathrm{df}$ & SS & MS & F & $\mathrm{p}>F$ \\
\hline \multicolumn{6}{|l|}{ ANE } \\
\hline Model & 8 & 273.341 & 34.167 & 48.76 & 0.0001 \\
\hline T & 2 & 208.496 & 104.248 & 148.76 & 0.0001 \\
\hline $\mathrm{S}$ & 2 & 57.515 & 28.757 & 41.04 & 0.0001 \\
\hline TS & 4 & 7.329 & 1.832 & 2.61 & 0.0549 \\
\hline Error & 30 & 21.024 & 0.700 & & \\
\hline Total & 38 & 294.365 & & & \\
\hline \multicolumn{6}{|l|}{ UNE } \\
\hline Model & 8 & 4.860 & 0.607 & 73.58 & 0.0001 \\
\hline$T$ & 2 & 3.180 & 1.590 & 192.60 & 0.0001 \\
\hline S & 2 & 1.406 & 0.703 & 85.19 & 0.0001 \\
\hline TS & 4 & 0.273 & 0.068 & 8.27 & 0.0001 \\
\hline Error & 30 & 0.247 & 0.008 & & \\
\hline Total & 38 & 5.108 & & & \\
\hline \multicolumn{6}{|l|}{ NINE } \\
\hline Model & 8 & 1.106 & 0.138 & 167.01 & 0.0001 \\
\hline $\mathrm{T}$ & 2 & 0.740 & 0.370 & 446.95 & 0.0001 \\
\hline$S$ & 2 & 0.295 & 0.147 & 178.49 & 0.0001 \\
\hline TS & 4 & 0.070 & 0.017 & 21.29 & 0.0001 \\
\hline Error & 30 & 0.024 & 0.008 & & \\
\hline Total & 38 & 1.131 & & & \\
\hline \multicolumn{6}{|l|}{ NANE } \\
\hline Model & 8 & 0.295 & 0.037 & 131.02 & 0.0001 \\
\hline $\mathrm{T}$ & 2 & 0.149 & 0.075 & 265.71 & 0.0001 \\
\hline$S$ & 2 & 0.116 & 0.058 & 205.78 & 0.0001 \\
\hline TS & 4 & 0.029 & 0.007 & 26.29 & 0.0001 \\
\hline Error & 30 & 0.008 & 0.002 & & \\
\hline Total & 38 & 0.304 & & & \\
\hline \multicolumn{6}{|l|}{ ONE } \\
\hline Model & 8 & 3.264 & 0.408 & 5.27 & 0.0004 \\
\hline$T$ & 2 & 2.693 & 1.346 & 17.38 & 0.0001 \\
\hline S & 2 & 0.101 & 0.050 & 0.66 & 0.5257 \\
\hline TS & 4 & 0.468 & 0.117 & 1.51 & 0.2236 \\
\hline Error & 30 & 2.324 & 0.077 & & \\
\hline Total & 38 & 5.589 & & & \\
\hline \multicolumn{6}{|l|}{ TNE } \\
\hline Model & 8 & 425.468 & 53.183 & 49.10 & 0.0001 \\
\hline $\mathrm{T}$ & 2 & 364.615 & 182.307 & 168.29 & 0.0001 \\
\hline S & 2 & 53.848 & 26.924 & 24.85 & 0.0001 \\
\hline TS & 4 & 7.004 & 1.751 & 1.62 & 0.1958 \\
\hline Error & 30 & 32.498 & 1.083 & & \\
\hline Total & 38 & 457.966 & & & \\
\hline
\end{tabular}

semisulcatus at $40.5 \%$, and to account for 57,2 and $22 \%$ of total nitrogen excreted for Penaeus monodon at 30\% (Wajsbrot et al. 1989, Chen et al. 1994). In the present study, higher urea- $\mathrm{N}$ excretion with a concomitant higher hemolymph urea- $\mathrm{N}$ at $40 \%$ suggests that urea is formed. The composition of nitrogenous excretion of Scylla serrata is greatly affected by different salinity levels.

In crustaceans, nitrogenous excretion is affected by both extrinsic factors, such as temperature and salinity,
Table 2. Scylla serrata. The percentage of ammonia- $N$ excretion (ANE), urea-N excretion (UNE), nitrite- $N$ excretion (NINE), nitrate-N excretion (NANE), and organic-N excretion (ONE) from nitrogenous excretions of crabs maintained at different salinities (S) and temperatures (T)

\begin{tabular}{|cccrccc|}
\hline $\mathrm{T}\left({ }^{\circ} \mathrm{C}\right)$ & $\mathrm{S}(\%)$ & ANE & UNE & NINE & NANE & ONE \\
\hline \multirow{2}{*}{15} & 10 & 85.58 & 1.53 & 2.14 & 5.21 & 5.54 \\
& 25 & 76.05 & 10.92 & 2.52 & 4.62 & 5.89 \\
& 40 & 70.00 & 22.67 & 1.33 & 4.00 & 2.00 \\
25 & 10 & 82.02 & 4.28 & 2.23 & 4.97 & 6.50 \\
& 25 & 79.24 & 9.11 & 2.53 & 3.29 & 5.83 \\
& 40 & 56.16 & 30.14 & 0.91 & 3.65 & 9.14 \\
35 & 10 & 82.03 & 4.47 & 2.49 & 4.99 & 6.02 \\
& 25 & 74.27 & 11.40 & 2.60 & 5.53 & 6.20 \\
& 40 & 70.59 & 14.07 & 0.80 & 2.86 & 11.68 \\
& & & & & & \\
\hline
\end{tabular}

and intrinsic factors, such as molt cycle, nutritional level and neuroendrocrine control (Regnault 1987. Chen et al. 1994). Since the crabs used in the present study were at the intermolt stage and had been fasted for $1 \mathrm{~d}$, they were considered to be at the same nutritional level.

In crustaceans, metabolic pathways involved in nitrogen excretion are catabolism of amino acid (including certain amides), deamination of purine nucleotides with the formation of ammonia, uricolysis and the ornithine-urea cycle with the formation of urea, and degradation of nucleic acid with the formation of uric acid (Claybrook 1983, Regnault 1987). The ornithine-urea cycle initiates with the fixation of metabolic product of $\mathrm{NH}_{4}^{+}$and $\mathrm{HCO}_{3}^{-}$which is supplied from $\mathrm{CO}_{2}$ through carbonic anhydrase. The higher ammonia- $\mathrm{N}$ excretion at low salinity $(10 \%)$ suggests that catabolism of amino acid is required to reduce

Table 3. Scylla serrata. ANOVA table of hemolymph ammonia-N (HAN) and hemolymph urea-N (HUN) of crabs maintaned at different salinities (S) and temperatures (T) after $24 \mathrm{~h}$

\begin{tabular}{|c|c|c|c|c|c|}
\hline Source & $\mathrm{df}$ & SS & MS & $F$ & $p>F$ \\
\hline \multicolumn{6}{|l|}{ HAN } \\
\hline Model & 8 & 125.523 & 15.690 & 13.65 & 0.0001 \\
\hline$T$ & 2 & 6.865 & 3.432 & 2.99 & 0.0657 \\
\hline S & 2 & 103.879 & 51.939 & 45.18 & 0.0001 \\
\hline TS & 4 & 14.778 & 3.694 & 3.21 & 0.0261 \\
\hline Error & 30 & 34.487 & 1.149 & & \\
\hline Total & 38 & 160.010 & & & \\
\hline \multicolumn{6}{|l|}{ HUN } \\
\hline Model & 8 & 20071.115 & 2508.889 & 11.26 & 0.0001 \\
\hline $\mathrm{T}$ & 2 & 3974.501 & 1987.250 & 8.92 & 0.0009 \\
\hline S & 2 & 12319.739 & 6159.869 & 27.66 & 0.0001 \\
\hline TS & 4 & 3776.874 & 944.218 & 4.24 & 0.0077 \\
\hline Error & 30 & 6681.647 & 222.721 & & \\
\hline Total & 38 & 26752.762 & & & \\
\hline
\end{tabular}



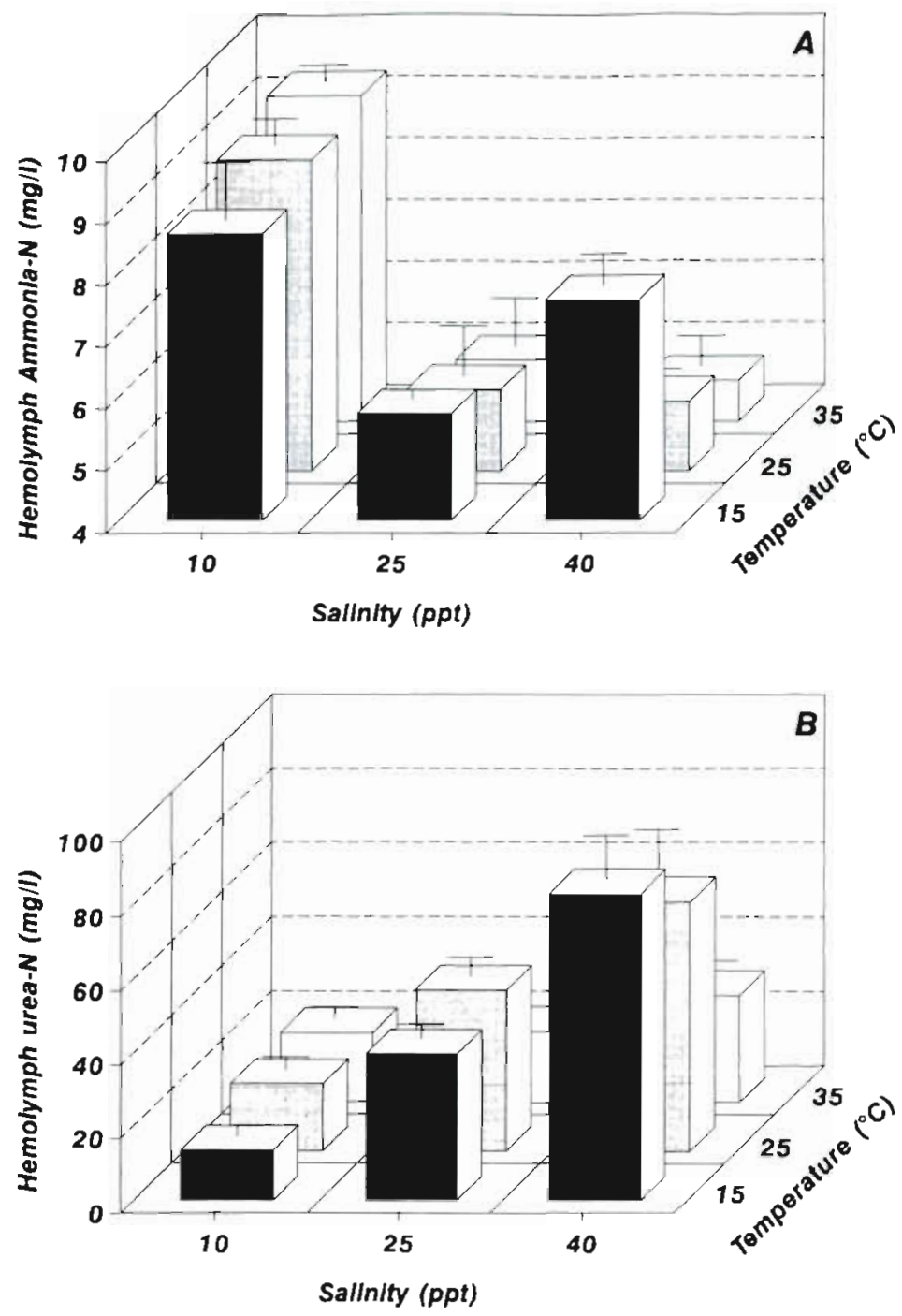

Fig. 4. Scylla serrata. Mean $\pm \mathrm{SE}$ (A) hemolymph ammonia-N and (B) hemolymph urea- $N$ of crabs maintained at dufferent salinities and temperatures after $24 \mathrm{~h} . \mathrm{n}=5$

osmolality. At higher salinity $(40 \%)$, Scylla serrata increased its urea excretion, which suggests that urea was synthesized and subsequently released for hyperregulation. A shift to increased excretion of urea at higher salinities has also been described in the crayfish Orconectes rusticus by Sharma (1968).

It is norteworthy that there is a small contribution from nitrite- $\mathrm{N}$ and nitrate- $\mathrm{N}$ excretion. The proportion of nitrite- $\mathrm{N}$ excretion was highest at $25 \%$ among the 3 salinity levels tested. The proportion of nitrate- $N$ excretion was high at $25 \%$ at $35^{\circ} \mathrm{C}$. After exposing Carcinus maenas to various salinity levels, Spaargaren (1985) reported that nitrate excretion was highest in brackish water and decreased at both higher and lower salinity levels and suggested that nitrate forma- tion may serve in the detoxication of ammonia and the maintenance of electroneutrality inside the crabs. Nitrite and nitrate are considered to be formed from the oxidation of nitric oxide (NO), which is produced by the conversion of L-arginine to $\mathrm{NO}$ and citrulline in the presence of NO synthetase in the arginine pathway (Tayeh \& Marletta 1989, Hrabak et al. 1992). For the final step of ornithine-urea, arginine is hydrolyzed by arginase and produces urea and ornithine (Regnault 1987).

Hemolymph ammonia- $\mathrm{N}$ has been reported to be 4.62 to $5.46 \mathrm{mg} \mathrm{l}^{-1}$ in blue crab Callinectes sapidus (Mangum et al. 1976, Cameron \& Batterton 1978), 3.50 to $13.23 \mathrm{mg}$ $1^{-1}$ in Carcinus maenas (Binns 1969, Harris \& Andrews 1985), and $37.42 \mathrm{mg} \mathrm{l}^{-1}$ in land crab Cardisoma carnifex (Wood \& Boutilier 1985). Hemolymph urea-N levels between 8.4 and $56 \mathrm{mg} \mathrm{l}^{-1}$ have been reported in Carcinus maenas (Binns 1969), and a level of $3.18 \mathrm{mg}$ $1^{-1}$ in Cardisoma carnifex (Wood \& Boutilier 1985). In the present study, hemolymph ammonia- $\mathrm{N}$ levels between 4.66 and $9.27 \mathrm{mg}$ $\mathrm{l}^{-1}$ and hemolymph urea- $\mathrm{N}$ levels between 13.41 and $82.82 \mathrm{mg} \mathrm{l}^{-1}$ were found for Scylla serrata and were dependent on salinity level.

In conclusion, the present study indicates that both temperature and salinity affect the nitrogen metabolism of Scylla serrata. In low salinity $(10 \%)$, there is catabolism of amino acid and formation of ammonia to reduce osmolality. However, at high salinity $(40 \%)$, there is an occurrence of urea synthesis and a shift of the nitrogen excretory pattern from ammoniotelism to ureotelism for hyper-regulation. Further research is needed to clarify the activities of enzymes like arginase, carbamoyl phosphate synthetase, and carbonic anhydrase involved in urea synthesis of crabs under different salinity conditions.

Acknowledgements. This paper was funded by the National Science Council (Grant No: NSC 84-2321-B019-014). We appreclate Mr S. Y. Cheng for his assistance with graphs.

\section{LITERATURE CITED}

Bendschneider $\mathrm{K}$, Robinson RJ (1952) A new spectrometnc method for the determination of nitrite in the sea water J Mar Res 11:87-96

Binns R (1969) The physiology of the antennal gland of Carcinus maenas (L.) $\mathrm{V}$ : some nitrogenous constituents in the blood and urine. J Exp Biol 51:41-51 
Bishop JS, Burton RS (1993) Amino acid synthesis during hyperosmotic stress in Penaeus aztecus postlarvae. Comp Biochem Physiol 106(A):49-56

Boone WR, Claybrook DL (1977) The effect of low salinity on amino acad metabolism in the tissues of the common mud crab Panopeus herbstii. Comp Biochem Physiol 57(A): 99-106

Cameron JN, Batterton CV (1978) Antennal gland function in the freshwater blue crab Callinectes sapidus: water, electrolyte, acid-base and ammonia excretion. J Comp Physiol 123:143-148

Chen HC, Cheng KH (1980) Studying on the larval rearing of mud crab Scylla serrata. China Fish Monthly 329:3-8

Chen JC, Chen CT, Cheng SY (1994) Nitrogen excretion and changes of hemocyanin, protein and free amino acid levels in the hemolymph of Pendeus monodon exposed to different concentrations of ambient ammonia- $\mathrm{N}$ at different salinity levels. Mar Ecol Prog Ser 110:85-94

Chen JC, Cheng SY (1995) Accumulation of urea in the haemolymph and ammonia excretion of Penaeus japonicus exposed to ambient nitrite. Comp Biochem Physiol 110(C): $1-6$

Claybrook DL (1983) Nitrogen metabolism. In: Mantel LH (ed) The biology of Crustacea, Vol 5, Internal anatomy and physiological regulation. Academic Press, New York, p $163-213$

Dalla Via GJ (1986) Salinity responses of the juvenile penaeid shrimp Penaeus japonicus II. Free amino acids. Aquaculture 55:307-316

Davenport J, Wong TM (1987) Responses of adult mud crabs (Scylla serrata) (Forskal) to salinity and low oxygen tension. Comp Biochem Physiol 86(A):43-47

Duncan DB (1955) Multıple-range and multiple F test. Biometrics 11:1 42

Fang LS, Tang CK, I ce DL, Chen IM (1992) Free amino acid composition in muscle and hemolymph of the prawn Penaeus monodon in different salinities. Nippon Suisan Gakkaishi 58:1095-1102

Freeman JA, Kilgus G, Laurendeau D, Penry HM (1987) Postmolt and intermolt molt cycle stages of Callinectes sapidus. Aquaculture 61:201-209

Gilles R, Péqueux A. (1983) Interaction of chemical and osmotic regulation with the environment. In: Vernberg FJ, Vermberg WB (eds) The biology of Crustacea, Vol 8, Environmental adaptation. Academic Press, New York, p $109-177$

Haberfield EC, Haas L, Hamman CS (1975) Early ammonia release by a polychaete Nereis virens and a crab Carcinus maenus in diluted seawater. Comp Biochem Physiol 52(A) 501-503

Harris RR, Andrews MB (1985) Total NPS pool and ammonia net efflux rate changes in Carcinus maenas durng acclimation to low environmental salinity. Comp Biochem Physiol 82(A):301-308

Hill BJ (1974) Salinity and temperature tolerance of zoeae of the portunid crab Scylla serrata. Mar Biol 25:21-24

Hill BJ, Williams MJ, Dutton P (1982) Distribution of juvenile, subadult and adult Scylla serrata (Crustacea: Portunidae) on tidal flats in Australia. Mar Biol 69:117-120

Hrabak A, Temesi A, Csuka I, Antoni F (1992) Inverse relation

This article was submitted to the editor in the de novo arginase synthesis and nitric oxide production in murine and rat peritioneal macrophages in longterm culture in vitro. Comp Biochem Physiol 103(A): $839-845$

Mangum CM, Silverthorn SU, Harris JL, Towle DW, Krall AR (1976) The relationshıp between blood $\mathrm{pH}$, ammonia excretion and adaptation to low salinity in the blue crab Callinectes sapidus. J Exp Zool 195:129-136

McCarthy JJ (1970) A urease method for urea in seawater Limnol Oceanogr 15:309-313

Needham AE (1957) Factors affecting nitrogen excretion in Crustacea. Physiol Comp Oecol 4:209-239

Nelson SG, Armstrong DA, Knight AW, Li HW (1977) The effects of temperature and salinity on the metabolic rate of juvenile Macrobrachium rosenbergii (Crustacea: Palaemonidae). Comp Biochem Physiol 56(A):533-537

Regnault $M$ (1987) Nitrogen excretion in marine and freshwater crustacea. Biol Rev 62:1-24

Robertson JD (1961) Studies on the chemical composition of muscle tissue. II. The abdominal flexor muscles of the lobster Nephrops norvegicus (L.). J Exp Biol 38:707-728

SAS (1988) SAS/STAT user's guide, 6.03 edn. SAS Institute Inc, Cary, NC

Sharma M (1968) Studies on the sources and mechanisms of increased urea production by Orconectes rusticus under osmotic stress. Comp Biochem Physiol 24:55-60

Siebers D, Lucu C, Sperling KR, Eberleın K (1972) Kinetics of osmoregulation in the crab Carcinus maenas. Mar Biol 17 291-303

Smith DM. Dall W (1991) Metabolism of proline by the tiger prawn, Penaeus esculentus. Mar Brol 11:85-91

Solorzano L (1969) Determination of ammonia in natural waters by the phenolhypochlorite method. Limnol Oceanogr 14:799-801

Solorzano L. Sharp JH (1980) Determination of total dissolved nitrogen in natural waters. Limnol Oceanogr 25:751-754

Spaargaren DH (1982) The ammonium excretion of the shore crab, Carcinus maenas in relation to environmental osmotic conditions. Neth J Sea Res 15:273-283

Spaargaren DH (1985) The significance of nitrate in the nitrogenous excretion of Carcinus maenas. Neth $\mathrm{J}$ Sea Res 19:119-124

Steel RGD, Torrie JH (1980) Principle and procedures of statistics. McGraw-Hill Inc, Now York

Tayeh MA, Marletta MA (1989) Macrophage oxidation of L-arginine to nitric oxide, nitrite and nitrate. Tetrahydrobiopterin is required as a cofactor J Biol Chem 264 $19654-19658$

Wajsbrot N, Krom MD, Gasith A, Samocha T (1989) Ammonia excretion of green tiger prawn Penaeus semisulcatus as a possible limit on the biomass density in shrimp ponds. Israel J Aquacult Bamidgeh 41:159-164

Wood CM, Boutilier RG (1985) Osmoregulation, ionic exchange, blood chemistry, and nitrogenous waste excretion in the land crab Cardisoma carnifex: a field and laboratory study. Bıol Bull Mar Biol Lab Woods Hole 169 $267-290$

Wood ED, Armstrong FA, Richards FA (1967) Determination of nitrate in sea water by cadmium-copper reduction to nitrite. J Mar Biol Ass UK 47:23-31

Manuscript first received: February 9, 1996

Revised version accepted: April 16, 1996 